\title{
Opinie
}

\section{Toezichthouders moeten het effect van hun eigen handelen beter gaan begrijpen}

Femke de Vries*

De AFM werkt sinds 2006 aan het verbeteren van de kwaliteit van de accountantscontrole. Een goede accountantscontrole zorgt dat we kunnen vertrouwen op wat bedrijven zeggen over hun financiële situatie.

De AFM constateerde dat, hoewel belangrijke stappen zijn gezet, de kwaliteit van de accountantscontrole nog altijd niet voldoende is. Waarom lukt het niet om die kwaliteit structureel te verbeteren? De AFM besloot een spade dieper te graven op zoek naar oorzaken van de achterblijvende kwaliteit. Want als weeffouten in het systeem in de weg staan aan kwaliteit, is duurzame verandering lastig.

Dat graven resulteerde in het rapport 'Kwetsbaarheden in de structuur van de accountancysector'. ${ }^{1}$ Een van de weeffouten die de AFM noemt, is het feit dat de accountantsorganisatie wordt betaald door de gecontroleerde onderneming. Daar ligt het 'wie betaalt, bepaalt'risico op de loer, waardoor de accountant onder druk van commerciële belangen niet onafhankelijk oordeelt. Daarnaast zijn accountants vaak partner in de eigen organisatie. Naast het publieke belang hebben ze te maken met het eigen financiële belang. Die belangen zijn niet altijd goed te verenigen.

Door op zoek te gaan naar de structurele oorzaken van het achterblijven van kwaliteit, tilt de AFM het toezicht naar een hoger niveau. Zo kunnen in het toezicht effectievere interventies worden ontwikkeld dan (alleen) het voortdurend wijzen op waar de sector tekortschiet. Dat kan als voorbeeld dienen voor andere toezichtgebieden waar kwaliteit of compliance hardnekkig achterblijven.

\footnotetext{
* Prof mr. dr. F. de Vries is bijzonder hoogleraar toezicht en managing partner van \&samhoud consultancy. Deze opinie is een bewerking van mijn expertbijdrage in Het Financieele Dagblad van 4 februari 2020.
}

1. www.afm.nl.
Naar aanleiding van het AFM-rapport stelde de minister van Financiën een commissie in die zich boog over de toekomst van de accountancysector (CTA). Deze laat ook haar licht schijnen over een element dat in het AFM-rapport onderbelicht is: het effect van het toezicht zélf. CTA-voorzitter Annetje Ottow stelt dat het toezicht heeft bijgedragen aan het verbeteren van de kwaliteit van de controle, maar is kritisch over de effectiviteit van het toezicht op termijn. 'Alleen maar blijven hameren op de fouten is niet altijd verstandig.' ${ }^{2}$ Daarmee raakt ze een belangrijk aspect dat altijd onderdeel zou moeten zijn van de analyse van een toezichthouder, namelijk de vraag of toezicht strategisch gedrag of onbedoelde effecten veroorzaakt.

De CTA beschrijft een antal van deze onbedoelde gevolgen van toezicht zoals het risico dat door gedetailleerde toezichteisen veel aandacht gaat naar het garanderen van een 'AFM-proof'-dossier. Zo wordt het voldoen aan de toezichteisen het doel in plaats van een middel. Het risico bestaat dat de accountant mist wat er speelt als zijn aandacht wordt opgeslokt door detaileisen aan het dossier. De angst voor een 'fout' dossier kan er ook voor zorgen dat hij geen verantwoordelijkheid neemt in gevallen waarin de norm niet volstrekt duidelijk is, terwijl juist dan het professionele oordeel van de accountant van belang is.

Hoe komen onder toezicht staande en toezichthouder in dit mechanisme terecht? De toezichthouder zit vaak niet voor niets dicht op de sector. Hij wil zien dat het accountantskantoor, de zorginstelling of de bank voortgang boekt na een groot incident of langdurig niet voldoen aan de eisen. Daarbij speelt ook dat hij zelf verantwoording moet afleggen over zijn toezicht. Dat gaat

2. 'Als het aan ons ligt raken accountants flink deel van hun zeggenschap kwijt', Het Financieele Dagblad 30 januari 2020. 
makkelijker met gedetailleerde controleerbare doelen en kwaliteitseisen.

Het nadeel is echter dat het opleggen van gedetailleerde eisen op termijn leidt tot minder eigenaarschap bij de onder toezicht staande. Uit de psychologie blijkt dat wanneer we autonomie ervaren en invloed hebben op ons eigen handelen, we gemotiveerder en met energie doelen nastreven. Die motivatie neemt af als een onder toezicht staande geen eigenaarschap voelt. Zo heeft het stellen van strikte toezichteisen dus een averechts effect. De oplossing is in het verleden gezocht in open normen. De wet bepaalt dan welk doel moet worden bereikt en laat de wijze waarop vrij. Dat werkt alleen als de toezichthouder vertrouwen heeft in de kunde en goede wil van de onder toezicht staande. Het is logisch dat dit na grote incidenten ontbreekt. Maar het stellen van gedetailleerdere eisen is niet de oplossing.

Om het systeem te laten werken moeten onder toezicht staande partijen laten zien dat ze écht de intentie hebben om bij te dragen aan het doel van de wet. Het vraagt ook van de toezichthouder dat hij regelmatig de onbedoelde gevolgen van zijn toezicht onder de loep neemt, bij voorkeur in een open dialoog met de onder toezicht gestelde, waarin ook van perspectief wordt gewisseld. Dat staat niet in de weg aan onafhankelijk toezicht. Het draagt er juist aan bij.

Sterker nog: wanneer die dialoog uitblijft, wordt een nieuwe weeffout aan het systeem toegevoegd. Ongewenste neveneffecten van toezicht kunnen er immers toe leiden dat het publieke belang niet dichterbij komt maar juist verder uit beeld raakt.

Ottow besluit met de oproep aan partijen in de accountancysector uit de loopgraven te komen en in gesprek te gaan. Het is belangrijk dat dit gesprek ook plaatsvindt in andere sectoren. Dat is de verantwoordelijkheid van toezichthouders én onder toezicht gestelden, om te voorkomen dat we ook elders in de loopgraven terechtkomen waar de AFM en accountants nu uit moeten komen. 